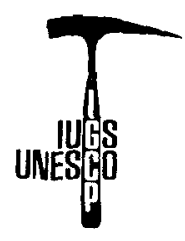

\title{
The Paradox of Late Proterozoic Glaciations at Low Latitudes
}

\author{
by Nicolai M. Chumakov and Donald P. Elston
}

The aim of IGCP Project 260 (Earth's Glacial Record), which began in 1987, is to investigate the relationships between past glaciations and global climate and geodynamics. This article reviews the setting for one of the subprojects, which is concentrating on the conflict between paleomagnetic results and paleoclimate indicators for the Late Proterozoic. The topic for another subproject is the relationship between plate tectonics and glaciation, possibly in terms of the Wilson cycle, $\mathrm{CO}_{2}$ de-gassing of the oceanic crust and paleoclimates. This is described briefly by G.M. Young in the box that follows. (Ed.)

\section{Introduction}

Lithologic and biologic indicators of climate define systematic, latitudinally distributed climatic zones on continental reconstructions for the Phanerozoic, suggesting that an analogous climatic zonation should also be possible for the Late Proterozoic. However, the distribution of warm-arid and glacial paleoclimatic indicators has been found to be highly irregular on a continental reconstruction for the latest Proterozoic (Vendian), and no global paleoclimatic zonation can be presently defined. The apparent lack of a climatic zonation would seem to indicate either that the paleoclimatic-paleomagnetic reconstruction and the low paleomagnetic inclinations are invalid, or that the distribution of paleoclimate indicators reflects significant changes in the Earth's climatic system during the Late Proterozoic.

The paradox of glaciations at low latitudes, inferred from paleomagnetic inclinations in Late Proterozoic strata containing glacial deposits, remains a major problem in geology. The paradox first arose from the early paleomagnetic studies of Harland and Bidgood (1959) and Bidgood and Harland (1961), supported by a number of later paleomagnetic studies (Runcorn, 1970; Piper, 1973; Tarling, 1974; Hambrey and Harland, 1981; Zhuhong, 1983). A widespread distribution of Late Proterozoic diamictite localities paralleling the low paleolatitudes inferred from paleomagnetic data appeared to support the paradox.

Several hypotheses were proposed in attempts to get around the problem. One supposes that the diamictites may be non-glacial (e.g. Volin, 1966; Klitin, 1965), though they may in places contain clasts derived from mountain glaciations (Schermerhorn, 1974, 1983). A second suggests that the glacial deposits accumulated on plates that moved through high and middle latitudes, with the low paleoinclinations superimposed after the fast-moving plates had entered low latitudes (Crowell, 1983). A third explanation holds that the diamictites are glacial and accumulated during global or near-global glaciations (e.g. Harland, 1964; Hambrey and Harland, 1985). In another hypothesis, Williams (1975) suggested that low-latitude glaciations were the result of an increased inclination of the Earth's axis of rotation with respect to the plane of the ecliptic. Finally, Sheldon (1984) has proposed that the low-latitude glaciations were the result of shading of the Earth's equator by an icy ring similar to that of Saturn.

The first two hypotheses are difficult to support on geological and paleomagnetic grounds. The claim that the diamictites are not glacial has been undermined by studies that have shown that many (if not most) of the deposits that had been called diamictites are indeed glacial or glaciomarine in origin (e.g. Dow, 1965; Chumakov, 1968; Bessanova and Chumakov, 1969; Isotta et al., 1969; Spencer 1971; Zubtsov, 1972; Trompette, 1973; Young, 1970, and Deynoux, 1978). The Crowell hypothesis does not explain the generally low-latitude positions for cratons throughout most of Middle and Late Proterozoic time, regardless of the presence or absence of diamictites in the sections, and it does not account for a lack of relict magnetizations (arising from incomplete overprinting) that would record the postulated excursions into high latitude positions at the times of glaciation. In order to evaluate the other three hypotheses, which all accept the low-latitude positions of the glaciations, we briefly review some paleoclimate data.

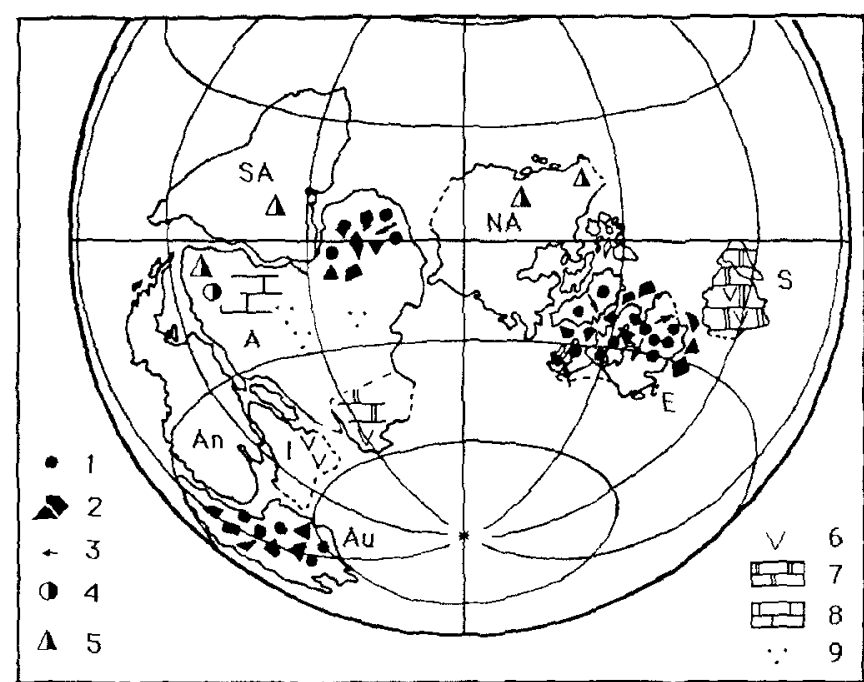

Figure 1: Distribution of climatic indicators for Vendian time ( 560 a $680 \mathrm{Ma}$ ) plotted on plate reconstruction of Khramov (1983, Fig. Ia) for the vendian System. Explanation: I - continental glacial deposits; 2 - mainly marine glacial deposits; 3 - direction of ice movement; 4 seasonal ice deposits; 5 - diamictites of possible Vendian age; 6 - evaporites; 7 - thick section of dolomite; 8 - thick section of limestone; 9 - limy red beds; A - Africa; An - Antarctica; $A u$ Australia; E - Europe; I - India; NA - North America; SA - South America; S - Siberia. 
The principal climatic zones today consist of tropical arid zones flanking a humid equatorial zone. The arid zones, in turn, are flanked by wetter and cooler climatic zones, and these give way to the glacial regimes of the polar regions. These strongly contrasting climatic zones appear to have been present during intervals of Phanerozoic glaciation (e.g., Early Permian and Pleistocene; Chumakov, 1985, 1986). During non-glacial periods, warm extra-tropical and warmtemperate climates occurred at middle and high latitudes (e.g. during the early Paleozoic, Mesozoic, and early Cenozoic; see Chumakov, 1985).

The latitudinal distribution of the climate zones is apparent in paleomagnetically controlled plate reconstructions for the Paleozoic. However, at least one
anomaly exists. In a reconstruction for Eariy Carboniferous time the equatorial climatic zone is tilted in a distinct northwesterly sense across North America with respect to the equator (Chumakov, ibid.). Nonetheless, paleolatitude spectra for the Phanerozoic indicate that glacial and seasonal ice deposits accumulated no closer to the equator than $30^{\circ}$ Iatitude, and that evaporite deposits and biogenic reefs accumulated no farther from the equator than $35^{\circ}$ to $50^{\circ}$.

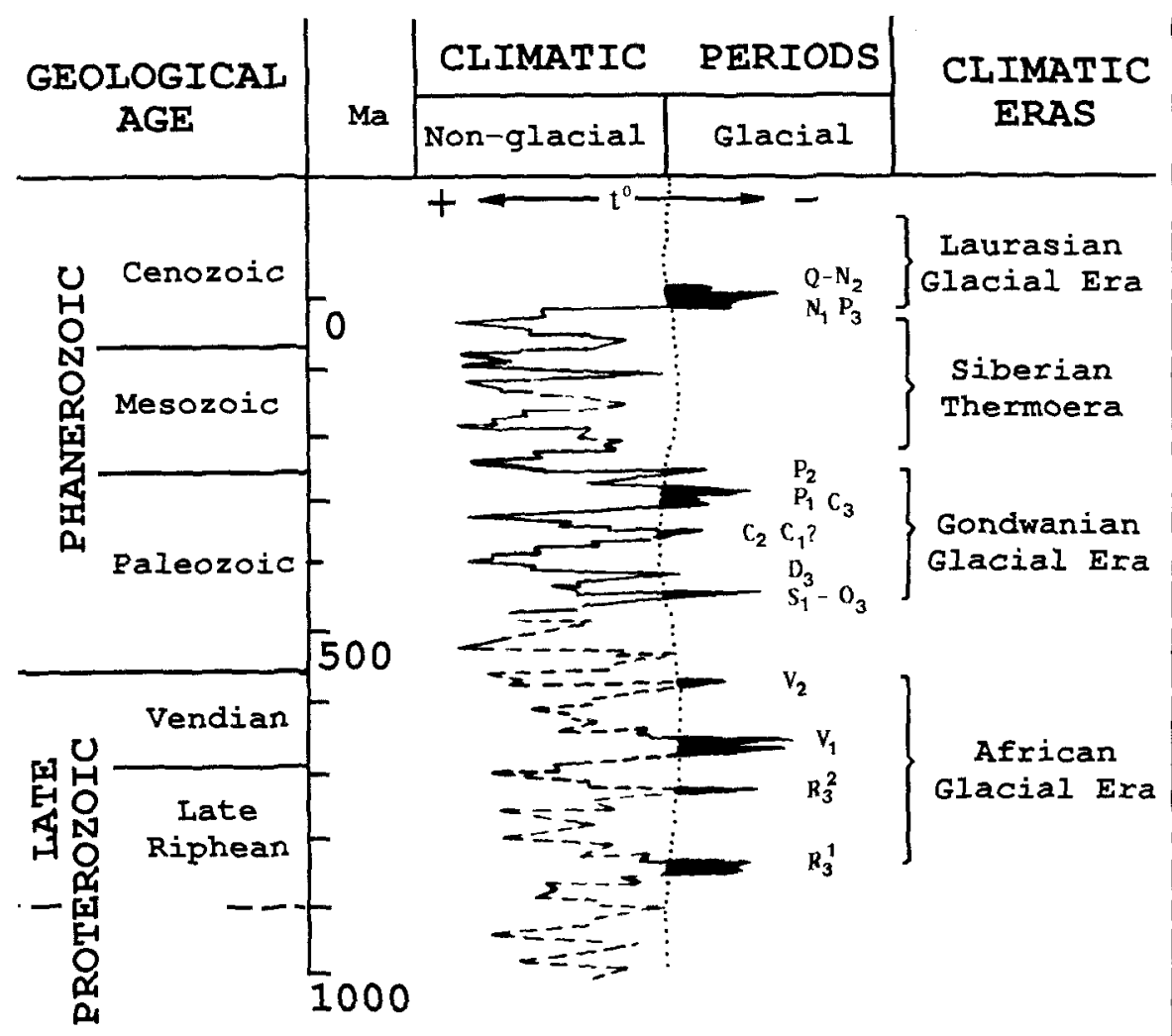

An attempt then was made to apply the same paleoclimatic approach to the Late Proterozoic (Fig. 1). Deposits of the Vendian System (Sokolov et al., 1985) ranging from about 650 to $560 \mathrm{Ma}$ old were chosen to represent the best-studied interval of latest Precambrian rocks. Lithologic indicators of climate from these rocks were derived from several sources (Vinogradov, 1967; Keller et al., 1974; Stocklin, 1968; Semikhatov, 1974; Khomentovskiy, 1976; Khain et al., 1981; Ronov et al., 1981; Young, 1981; Preiss, 1987). The climate indicators then were plotted with respect to a paleomagnetic plate reconstruction of Khramov (1983, fig. la). A reconstruction for this interval by Piper (1982) is similar to that of Khramov, and reconstructions by Morel and Irving (1978), Osipova (1981), Monin and colleagues (1986), and others show similar paleolatitudinal positions for the continents.

No regularities in the distribution of climate indicators and no climatic zonations are recognized for the Vendian (Fig. 1). Climate indicators that record warm-arid conditions (evaporites, carbonates, limy terrigenous red beds) are in proximity to and at the same latitudes as glacial deposits. In general, the indicators of climate for the Vendian have irregular, spotty distributions, and some glacial deposits appear to be flanked in space by evaporites (e.g., compare Europe-Greenland with Siberia on Figure 1). The paleolatitude spectra of the glacial and evaporite deposits on Figure 1 are similar, ranging from $+10^{\circ}$ to $-62^{\circ}$ and $0^{\circ}$ to $-60^{\circ}$, respectively. These Vendian distributions differ markedly from those in the Phanerozoic and appear abnormal with respect to the distribution expected for deposits that reflect glacial and warm-arid conditions. In view of this, the paradox of low-latitude glaciation in the Late Proterozoic perhaps can be regarded as part of a more general paleoclimatic paradox.

The problem might be assumed to result from a failure of the plate reconstruction shown in Figure 1 arising from invalid paleomagnetic data, or the paradox might be attributed, partly or wholly, to dramatic changes in the
Figure 2: Distribution of principal glacial episodes during past $1000 \mathrm{Ma}$ (from Chumakov, 1986). Explanation: $Q-N_{2}, N_{1}, P_{3}$ - Iate Cenozoic; $P_{2}$ - Late Permian: $P_{1}, C_{3}-$ Early Permian and late Carboniferous; $C_{2}, C_{1}$ ? - middle and early Carboniferous; $D_{3}$ - Devonian; $S_{1}, O_{3}-$ Early Silurian and Late Ordovician; $V_{2}$ - Late Venidan; $V_{1}$ - early Vendian; $R_{3}$ - late Riphean, 2-late. 1 -early.

Earth's climatic system. In the latter case, the times of change presumably would include not only three potentially discrete Vendian glaciations but also two older late Riphean glaciations (Fig. 2).

The apparently abnormal distribution of climatic indicators cannot be explained by any of the five general hypotheses listed previously. Moreover, the explanation involving increased inclination of the Earth's rotation axis appears not to be valid for three different reasons. First, it does not explain the wide distribution in latitude $\left(0^{\circ}-60^{\circ}\right)$ of the glacial and evaporite deposits (Fig. 1). Second, an increase in inclination of the Earth's axis of rotation is a feature to be expected in the distant future rather than in the geologic past (Hunt, 1979; Monin and Sishkov, 1979). Third, convective heat transfer by the Earth's atmosphere and ocean circulation appears to have generally compensated for the large negative radiation balance of high-latitude parts of the globe during the non-glacial parts of the Phanerozoic. The circulations also should have been adequate to dampen a lesser seasonal radiation balance of low latitudes in the case of a high angle inclination of the Earth's axis of rotation.

Sheldon's (1984) hypothesis that the equatorial region was shaded by an icy ring does not accord with the low-latitude distribution of some of the evaporites, or with the middlelatitude distribution of some of the glacial deposits. Lastly, a hypothesis calling for global or sub-global glaciations does not accord with the wide distribution in paleolatitude of the Vendian evaporites and the regional limitations of the 


\section{GLACIATION AND TECTONICS}

Part of the mandate of IGCP Project 260, "Earth's Glacial Record," is to investigate possible relationships between glaciation and tectonics. During the early history of the Earth, according to astronomical theory, solar luminosity, should have been about $25 \%$ less than at present. It is therefore puzzling that there are so few well documented examples of glacigenic rocks in the Archean. Possibly the primitive Earth was enveloped in an atmosphere rich in greenhouse gases, so that even the weakly radiative sun produced sufficient heat to prevent widespread glaciation.

Glaciation is manifested in both the Early and Late Proterozoic, but there is a long time interval, between about $2.0 \mathrm{GA}$ and $1.0 \mathrm{Ga}$ ago, when there is no record of glaciation on Earth. The absence of glacial deposits over such a long time span is perhaps more puzzling than its occurrence in the preceding and subsequent parts of the Proterozoic record.

Figure $A$ is an attempt to represent schematically the stratigraphic (and inferred plate tectonic) setting of Early Proterozoic rocks of North America. This generalized reconstruction is based on the Huronian Supergroup of Ontario, the Snowy Pass Supergroup in Wyoming and the Hurwitz Group in the Northwest Territories The critical feature is the preservation of glacigenic rocks in what are interpreted as the rift and rift-drift transition phases. In the southern hemisphere, Early Proterozoic glacigenic rocks are best known from South Africa and Western Australia. The stratigraphic context is well documented, but the plate tectonic setting is at best speculative. In Figure $B$ it is tentatively suggested that these local glacial deposits could be related to the closing phases of a Wilson cycle. Ironformations in the Early Proterozoic formed in siliclasticstarved basins and may have been largely hydrogenous.

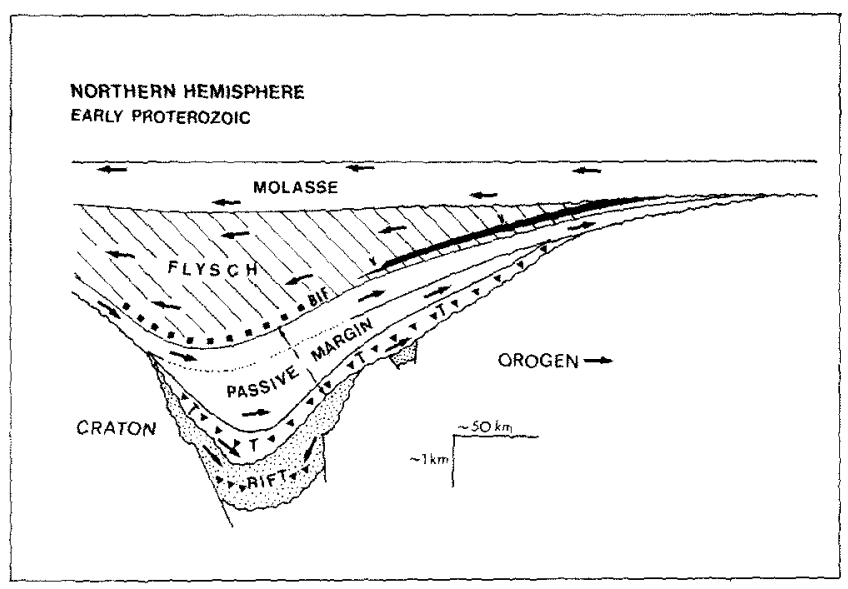

Figure A: Schematic representation of inferred plate tectonic setting of glacigenic rocks (triangles and letter " $T$ " indicate glacigenic deposits) in Early Proterozoic successions of the northern hemisphere. Arrows represent major sediment transport directions. Note that evidence of glaciation is preserved in the rift phase and at the rift-drift transition. Iron-formation (BIF) occurs near the base of the foreland basin flysch.
Late Proterozoic glacigenic deposits are known from all continents. Most of these rocks are preserved in what are interpreted as rift basins, precursors to the break-up of a Late Proterozoic supercontinent. Intimately associated iron-formations are probably related to hydrothermal exhalations accompanying the rifting process.

Recent studies of Phanerozoic glacigenic deposits and paleoclimates in general have led to the suggestion that climatic change on Earth over the last $600 \mathrm{Ma}$ is related primarily to fluctuations in the $\mathrm{CO}_{2}$ content of the atmosphere. These changes, in contrast to the recent industrial atmospheric pollution, are related to plate tectonic processes. Cold periods ("icehouse effect") appear to be linked to two plate tectonic configurations: one related to the existence of a high-standing supercontinent and the other to periods, like the present, when an expanding Atlantic-type ocean approached its maximum extent leading to a high percentage of "old," dense oceanic crust that sinks and causes lowering of relative sea level. Under both conditions, the continents are high standing. Most of the Early and Late Proterozoic glacigenic occurrences probably fall into the first category whereas the Pleistocene glaciation would be of the second type.

\begin{tabular}{|c|c|c|c|}
\hline & \multicolumn{2}{|c|}{ Early Proterozoic } & \multirow{2}{*}{$\frac{\text { Late Prot }}{\text { Global }}$} \\
\hline & N. Hemisphere & S Hemisphere & \\
\hline คIFT & & & $\begin{array}{l}\text { HYDROTHERMAL } \\
\text { ACTIVITY }\end{array}$ \\
\hline MIOCLINE & CLASTIC & CHEMICAL & \\
\hline FOREDEEP & $\begin{array}{l}\text { CLATrut- } \\
\text { CLASTIC }\end{array}$ & W'MASTIC & \\
\hline & much dissolver & $F_{0}$ in oceans & little $F_{e}$ \\
\hline
\end{tabular}

Figure B: Summary diagram to illustrate the inferred plate tectonic setting of Early and late Proterozoic glacigenic rocks ishown by cross hatching) and iron-formations (shown by thick black bars). Note that glacigenic rocks (and iron-formations) are interpreted to occur in different settings in the northern and southern hemispheres. Late Proterozoic glacigenic rocks and iron-formations are interpreted as rift-related deposits.

The link between plate tectonics and $\mathrm{CO}_{2}$ content of the atmosphere (and hence paleoclimate) seems at first obscure, but computer modeling has revealed that the most important factor in controlling atmospheric $\mathrm{CO}_{2}$ levels is the rate of degassing. A second important factor is the rate of weathering of continental crust, which increases during periods of low sea level. Degassing would be minimized, and continental weathering maximized during both conditions described above. Because of the marine transgressions that typically follow continental fragmentation the deposits of type " $a$ " glaciations should be preferentially preserved in the geologic record, and it is to this condition that most of the Proterozoic occurrences are ascribed.

G.M. Young

Department of Geology University of Western Onterio London, Ontario Canada N6A 5B? 


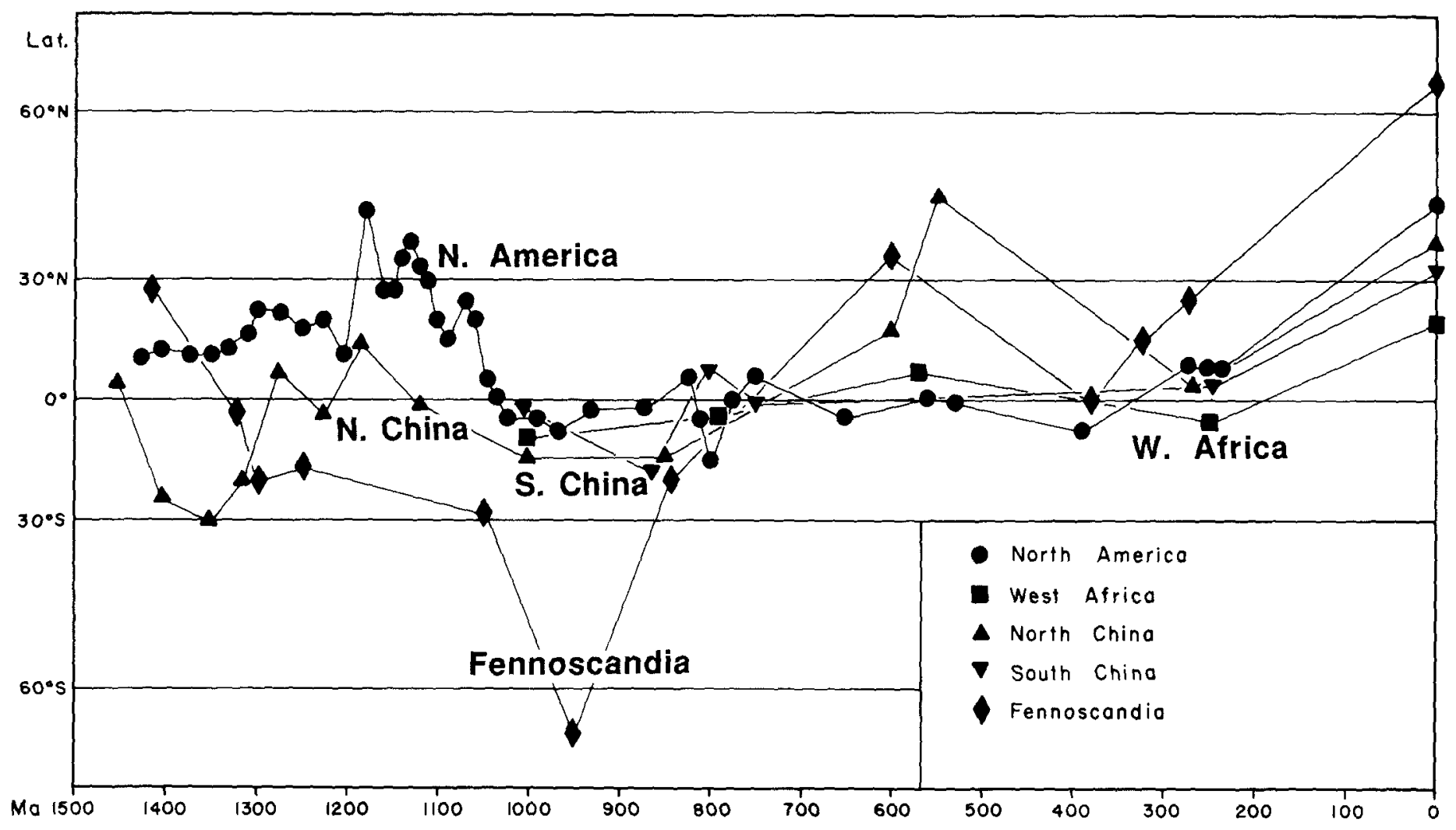

Figure 3: Paleolatitudes for interval $s 1,250-250$ $\mathrm{Ma}$ for several continents and subcontinents. Sources for data points. North America Proterozoic rocks: Middle Proterozoic Belt Supergroup, Montana and Idaho, and Middle and Late Proterozoic Grand Canyon Supergroup, northern Arizona, western U.S. (from Elston and Bressler, 1980, and in review; Elston and Grommé, 1975, 1979, 1984, and in review; and Elston, 1984, 1986, 1988a). Middle Proterozoic upper Keweenawan Jacobsville Sandstone of Keweenaw Peninsula, northern Michigan (Roy and Robertson, 1978); and upper Keweenawan Chequamegon Sandstone of northern Michigan, (MCCabe and Van der Voo, 1983). Late Proterozoic Uinta Mountain Group, Utah and Colorado (Bressler, 1981). Late Proterozoic Little Dal Group, Mackenzie Mountains, northwest Canada (Park, 1981a); and $5770-M a$ sills in Tsezotene Formation beneath Little Dal Group (Park, 1981b; Armstrong and others, 1982; Park and Aiken, 1986). Z component of magnetization in glaciogenic Late proterozoic Rapitan Group, Windermere Supergroup, western Canada (Morris, 1977). Late Proterozoic Franklin intrusions ( $600-650 \mathrm{Ma}$ ), northern Canada (Palmer and Hayat.su, 1975). Paleozoic strata: Poles and provisional polar path for Cambrian to Permian rocks including Lower to Midale Cambrian Tapeats Sandstone, and Middle Cambrian Bright Angel Shale, Grand Canyon (Elston and Bressler, 1977, 1984; Elston, 1988b); Silurian Rose Hill, Hersey, and Wabash Formations, eastern and central U.S.A. (French and Van der Voo, 1979; Kent and Opdyke,
1980; McCabe and others, 1985); Devonian Maywood Formation, western Montana (Elston and Bressler, 1984; Elston 1988b); Carboniferous strata of New Brunswick (Roy and Robertson, 1968; Roy and Park, 1969, 1974; Roy, 1977); preliminary pole from PennSylvamian strata of Supai Group, Marble Canyon (D.P. Elston, unpublished data); pole from six sites in Lower Permian strata of Supai Group of northern and central Arizona (Chino Point (Steiner, 1988) and Sedona (Elston, 1988b), and Lower Permian Abo Formation of New Mexico (Steiner, 1988)); Late(?) permian overprint pole on Cambrian and Devonian strata, northern and central Arizona (Elston, 1988b); Lower and Middle(?) Triassic Moenkopi Formation, northern Arizona (Purucker and others, 1980). West Africa (Mauritania), Perrin and others (1988); North China (Jixian section); Elston and others, (1989); South China (Changhe section), Zhang and others, (1989); Fennoscandia, L.J. Pesonen, (written communication, 1988). The southerly high-latitude shift of the pole for R950 Ma for Fennoscandia also is seen in a polar path proposed from the crystalline Grenville province of North America (e.g. Berger and others, 1979; Dallmeyer and Sutter, 1980). This southerly shift is not seen in poles from the tilt-corrected stratified rocks of the western cordillera, and therefore has not been shown on the plot of paleoinclinations for North America. Note also that the paleolatitude of Fennoscandia for the Vendian assumes an opposite polarity from that used for the reconstruction in Figure 1. 
individual, discrete Vendian glacial deposits (Chumakov, 1978; Hambrey and Harland, 1985; Sokolov et al., 1985). Unfortunately, the close temporal control needed to evaluate the contemporaneity of individual glacial and warm periods on a global seale for the Vendian still is lacking, an uncertainty that also exists for an Ordovician-Silurian reconstruction (Chumakov, 1985).

\section{Paleomagnetic Paleolatitudes}

Paleomagnetic studies continue to reinforce the earlier conclusion that many Late Proterozoic sequences on different continents accumulated at low paleolatitudes. As displayed on Figure 3, paleolatitudes for the cratonic areas shown remained generally low throughout the Middle and Late Proterozoic and for much of Paleozoic time. Paleolatitudes inferred from the low inclinations provide no evidence to support excursions of the plates from low to moderate or high latitudes that might correlate with one or more episodes of Late Proterozoic glaciation. If the paleomagnetic data shown on Figure 3 are accepted at face value, glacial deposits contained in the Late Proterozoic sequences accumulated at low latitudes.

It is true that glacial deposits in the Late Proterozoic sections generally do not contain stable remanent magnetizations and that their low paleolatitudes are inferred from low inclinations in strata that enclose or are broadly correlative with the glacial deposits. Nonetheless, the directions of remanent magnetization from the enclosing or correlative strata have been determined following appropriate and extensive thermal and alternating-field cleaning, and have been calculated from clusters of sample and site directions lacking "streaks" that would reflect unremoved components of secondary magnetization. In some cases, the paleomagnetic directions are supported by antiparallel reversals, indicative of a lack of significant secondary magnetizations. In other cases, the low paleomagnetic inclinations have come from igneous rocks, so ad hoc appeals to unrecognized secondary magnetizations residing in certain rock types (e.g. red beds) also appear not to be valid.

Thus, no evidence is recognized that supports the proposal that low inclinations are the consequence of secondary overprinting following movement of plates from high or moderate latitudes into lower latitude positions. Remnants of "pre-overprint," higher latitude inclinations should have been detected if the plates had undergone rapid movement, first toward and then away from the pole to produce the contained glaciations at high or even middle latitudes.

\section{Summary}

The problem of the paradox of low-latitude glaciations during the Late Proterozoic remains unresolved, but the problem now can be regarded as part of a more general paradox. Two potential causes for the paradox are that either the paleomagnetic reconstructions and paleolatitudes (Khain and Yasamanov, 1987) or the paleoclimatic reconstructions are incorrect. However, creditable scenarios allowing the paleomagnetic or paleoclimatic data sets to be discarded do not appear to exist.

If the irregular distribution of climate indicators and the apparent lack of a climatic zonation during the Late Proterozoic is real, multiple and dramatic changes in the Earth's climate system can be inferred to have occurred during the Late Proterozoic. Rejection of paleolatitudes derived from inclination data is a much more difficult proposition than the rejection of any particular continental reconstruction based on pole positions. We also note that if glacial deposits were not present in the Late Proterozoic sections, no reason would exist to question the validity of the low paleomagnetic inclinations and the generally low paleolatitudes of accumulation.
Dr. N.M. Chumakov, (Geological Institute of the U.S.S.R. Academy of Sciences, Pyzchevski 7, Moscow 109017 , U.S.S.R.), is a co-leader of the Paleomagnetism and Geochronology subproject of IGCP-260. $\mathrm{His}$ research concentrates on late Precambrian stratigraphy and glaciations.

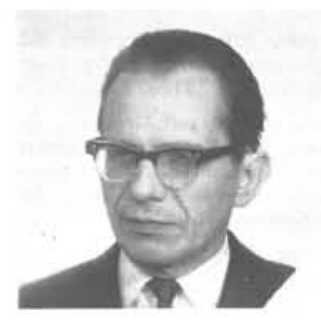

Dr. D.P. Elston, (U.S. Geological Survey, Flagstaff, Arizona 86001, U.S.A.), is the other Co-leader of the Paleomagnetism and Geochronology subproject of IGCP-260. He has been pursuing the character of Proterozoic and Paleozoic paleomagnetic records on different continents with the object of developing high resolution intercontinental correlations.

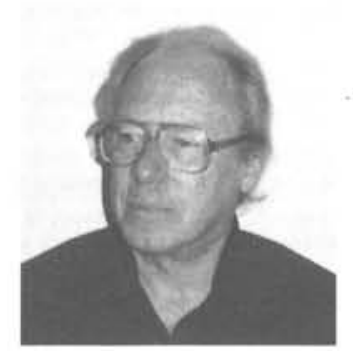

\section{References}

Armstrong, R.L., Eisbacher, G.H. and Evans, P.D., 1982. Age and stratigraphictectonic significance of Proterozoic diabase sheets, Mackenzie Mountains, northwestern Canada. Canadian Journal of Earth Sciences, v. 19, no. 2, p. 316-323.

Berger, G.W., York, D. and Dunlop, D.J., 1979. Calibration of Grenvillian palaeopoles by $40_{\mathrm{Ar}} /{ }^{39} \mathrm{Ar}$ dating. Nature, v. 277 , no. 5691 , p. $46-48$.

Bessanova, V.Y. and Chumakov, N.M., 1969. Upper Precambrian glacial deposits of western U.S.S.R. Lithology and Mineral Resources, no. 2, p. 73-89.

Bidgood, D.E.T. and Harland, W.B., 1961. Palaeomagnetism in some East Greenland sedimentary rocks. Nature, London, v. 189, no. 4765, p. 633-634.

Bressler, S.L., 1981. Preliminary paleomagnetic poles and correlation of the Proterozoic Uinta Mountain Group, Utah and Colorado. Earth and Planetary Science Letters, v. 55, no. 1, p. 53-64.

Chumakov, N.M., 1968. On the nature of Late Precambrian glaciation of Spitsbergen. Doklady of U.S.S.R. Academy of Sciences, v. 180, no. 6, p. 1446-1449, (English translation p. 115-118).

Chumakov, N.M., 1978. Precambrian tillites and tilloids. Moscow, Nauka, 201p., (in Russian).

Chumakov, N.M., 1985. Glacial events of the past and their geological significance. Palaeogeography, Palaeoclimatology, Palaeoecology, v. 51, no. 1-4, p. 319-346.

Chumakov, N.M., 1986. What climate is typical for Earth? Priroda, no. 10, p. 34-45 (in Russian).

Crowell, J.C., 1983. Ice ages recorded on Gondwanan continents. Transactions of the Geological Society of South Africa, v. 86, no. 3, p. 238-261.

Dallmeyer, R.D. and Sutter, J.F., 1980. Acquisitional chronology of remanent magnetization along the "Grenville polar path": Evidence from $40_{\mathrm{Ar}} / 3^{39} \mathrm{Ar}$ ages of hornblende and biotite from the whitestone diorite, Ontario. Journal of Geophysical Researeh, v. 85, no. B6, p. 3177-3186.

Deynoux, M., 1978. Les formations glacialires du Precambrien terminal et de la fin de l'Ordovicien en Afrique de l'Ouest; deux examples de glaciation d'inlandsis sur une plate-forme stable. Travaux des Laboratoires des Sciences de la Terre, Serie B une plate-forme stable. Travaux
, Serome, Marseille, 554p.

Dow, D.B., 1965. Evidence of a Late Pre-Cambrian glaciation in the Kimberley Region of Western Australia. Geological Magazine, v. 102, no. 5, p. 407-414.

Elston, D.P., 1984. Magnetostratigraphy of the Belt Supergroup - a synopsis. Montana Bureau of Mines and Geology, Special Publication 90, Abstracts with Summaries, Belt Symposium II, Missoula, p. 88-90.

Elston, D.P., 1986. Magnetostratigraphy of Late Proterozoic Chuar Group and Sixtymile Formation, Grand Canyon Supergroup, northern Arizona: Correlation with other Proterozoic strata of North America. Geological Society of America Abstracts with Programs, v. 18, no. 5, p. 353.

Elston, D.P., 1988a. Grand Canyon Supergroup, northern Arizona: Stratigraphic summary and preliminary paleomagnetic correlations with parts of other North American Proterozoic successions. In: Reynolds, S.J. and Jenney, J.P. (eds.), SumAmerican Proterozoic successions. In: Reynolds, S.J. and Jenney,
mary of Arizona Geology. Arizona Geological Society Digest, v. 17.

Elston, D.P., 1988b. Paleomagnetic poles from Cambrian, Devonian, Pennsylvanian, and Permian strata of Arizona and Montana. Geological Society of America Abstracts with Programs, v. 20, no. 7, p. A350.

Elston, D.P. and Bressler, S.L., 1977. Paleomagnetic poles and polarity zonation from Cambrian and Devonian strata of Arizona. Earth and Planctary Science Letters, v. 36 , no. 3 , p. 423-433.

Elston, D.P. and Bressler, S.L., 1980. Paleomagnetic poles and polarity zonation from the Middle Proterozoic Belt Supergroup, Montana and Idaho. Journal of Geophysical Research, v. 85 , B1, p. 339-355. 
Esston, D.P. and Bressler, S.L., 1984. Devonian pole from Montana, and refined Paleozoic polar path for North America (Abstract). American Geophysical Union Transactions (EOS), v. 65, no. 45, p. 864-865,

tiston, D.P. and Grommé, C.S., 1974. Precambrian polar wandering from Unkar Group and Nankoweap Formation, eastern Grand Canyon, Arizone. In: Karistrom, T.N.Y., Swann, G.A. and Eastwood, R.L., (eds.), Geology of northern Arizona with notes on acchaeology and paleoclimate, Pt. i, Regional studies. Geological Society of America, Rocky Mountain Section Meeting, Flagstaff, Arizona, p. 97-117.

Elston, U.P. and Grommé, C.S., 1979. Paleomagnetic correlation of Late Proterozoic strata of Arizona and Lake Superior (abstract). American Geophysical Union Transactions (EOS), v. 60, no. 18, p. 236.

Elston, D.P., Zheng Huimin and Zhang Wenzhi, 1989. Paleomagnetism of Middle and Late Proterozoie Changeheng, Jixian, and Qingbaikou Groups, Jixian County, North China, Abstracts with Program, 28th Intemational Geological Congress, Washington, D.C.

French, A.N. and Van der Voo, R., 1979. The magnetization of the Rose Hill Formation at the classical site of Graham's fold test. Journal of Geophysical Research, v. $84, \mathrm{BI} 3$, p. $7688-7696$.

Hambrey, M.J. and Harland, W.B. (eds), 3981. Earth's PrePleistocene Glacial Record. Cambridge University Press, London and New York, $1004 p$.

Hambrey, M.J, and Harland, W.B., 1985. The Late Proterozoic glacial era. Palaeogeography, Palaeoclimatology and Palaeoecology, v, 5l, no. 1-4, p. 255-272.

Harland, W.B., 1964. Critical evidence for a great Infracambriar glaciation. Geological Rundschau, v. 54 , no. J, p. 45-61.

Hariand, W.B. and Bidgood, D.E.T., 1959. Palaeomagnetism in some Norwegian sparagmites and the late Pre-cambrian ice age. Nature, v. 134, p. 1860-1862.

Hunt, B.C., 1979. The effects of past variations of the Earth's rotation rate on climate. Nature, v. 281 , no. 5728 , p. $188-191$.

Isotta, C.A.L., Rocha-Campos, A.C. and Yoshida, K., 1969. Striatad pavement of the Upper Pre-cambrian glaciation in Brazil. Nature, v. 22, no. 5192, p. 466-468.

Keller, B.M., Aksenov, E.M., Korolev, B.G., Krylov, I.N., Rozanov, A.Y., Semikhatov, M.A. and Chumakov, N.M., 1974. Venoomiy (Terminal Riphean) and it regional units. In: Results of Sciences and Technical Development, Stratigraphy and Palentology. VINITI, Moscow, no. 5, p. 5-126 (in Russian).

Kent, D.V. and Opdyke, N. B., 1980. Paleomagnetism of Siluro-Devonian rocks from eastern Maine. Canadian Journat of Earth Seiences, v. 17, no. 12, D. 1653-1665.

Khain, V.E., Ronov, A.B, and Sesiavinskiy, K.B., 1981. Upper Riphean lithological complexes of world, Sovetskaya Geologiya, no. 1, p. 72-91 (in Russian).

Knain, V.E, and Yasamanov, N.A., 1987. Paradox of Late Precambrian glaciations and drift of continents. Vestnik, Moskovskogo universiteta, Series 4, Geologiya, no. 1, p. 15-25 (in Russian).

Khomentorsky, V.V., 19z6. Vendian. Trudy Instituta geologii

i geofisiki, Sibirskoe otdelenie, AN S.S.S.R., Memoir $24 \mathrm{~J}$

271 . (in Russian).

Klitin, K.4., 1965. Baikalian folding and tillite-like conglonerates in Caledonide sections of Europe and Creenland. Doklady Akademii nauk LI.S.S.R., v. 163, no. 3 ק. $702-705$.

Khramov, A.N., 1983. Global reconstruction of the position of ancient cratons during late Precambrian. in: Khramov, A.N. (ed.), Paleomagnetism of Upper Precambrian of U.S.S.R. VNIGKI, Leningrad, p. 127-137 (in Russian).

MoCabe, $C$. and Van der Voo, R., 1983. Paleomagnetic results from the upper Keweenawan Cheguamegon Sandstone: Implications for red bed diagenesis and late Precambrian apparent polar wander of North America. Canadian Journal of Earth Sciences, w. 20, no. 1, p. 105-112.

MoCabe, C., Van der Voo, R., Wilkinson, B.H, and Devaney, K., 198j. A Hiddle/Late Silurian paleomagnetic pole from limestone reefs of the Wabash Formation, Indiana, U.S.A. Journal of Geophysical Researeh, v. 90, B4, p. $2959-2965$.

Vonin, A.S. and Shishkov, Y.A., 1979. The History of Climate. Cidrometeoizdat, Leningrad, 407p. (in Russian).

Monin, A.S., Zonenshayn, L.P., Gozodnitskiy, A.M., Kaz'min, V.G., Kononov, M.V. and Nazarova, Ye.A., 1986. Paleomagnetism and pre-Gondwanian difit of continents. Doklady Akademii nauk U.S.S.R., v. 286, no. 6, p. $1355-1359$.

Morel. P. and lrving, E., 1978. Tentative paleseontinental maps for the early Phan erozoic and Proterozsic. Journal of Geology, v. 86, no. 5, p. 535-561.

Morris, W..., 1977. Paleclatitude of glaciogenic upper Precambrian Rapitan Group and the use of tillites as chronostratigraphic marker horizons. Geology, v. 5, no. 2, p. $85-88$.

Osipova, Ye.P., 1981. Problems of paleomagnetic correlations of Riphean and vendian deposits and problems of polarity in the paleogeography of the vendian. In: Paleomagnetism and Problems of Pateogeography. VNIGRl, Leningrad, p. 23-34 (in Paleomasne
Russian?

Palmer, H.C. and Hayatsu, A., 1975, Paleomagnetism and $\mathrm{h}-\mathrm{Ar}$ dating of some Franklin lavas and diabases, Victoria Island. Canadian Journal of Eartn Sciences, V. 12, no. 8, p. 1439-3447.

Park, J.K., 1981\%. Analysis of the multicomponent magretization of the Little Dal Groun, Mackenzie Mountains, Northwest Territories, Canada. Journal of Ceophysical Researeh, v. 86, B6, p. $5134-514 \dot{\partial}$.

Park, J.K., 1981b. Paleomagnetism of the late Proterozoic sills in the Tsezotene Formation, Mackenzie Mountains, Northwest Territories, Canada. Canadian Journal of Enrth Seiences, $\forall .18$, no. 10, p. 1572-1580.

Park, J.K. and Aiken, J.D., 1986. Paleomagnetism of the Late Proterozoic Isezotene Formation of northwestern Canada. Journal of Geophysical Research, v. 91, no. B5, p. $4955-4970$.
Perrin, M., Elston, D.P. and Moussine-Pouchkine, A., 1988. Paleomagnetism of Proterozoic and Cambrian strata, Adrar de Mauritainie, cratonic West Africa. Journal of Geophysical Research, v. 93, no. B3, p. 2159-2178.

Piper, J.D.A., 1973. Latitudinal extent of late Precambrian glaciations. Nature, v. 244 , no. 5415 , p. $342-344$.

Piper, J.D.A., 1982. The Precambrian palaeomagnetic record: The case for the Proterozoic Supercontinent. Earth and Planetary Science Letters, v. \$9, no. 1, p. $61-89$,

Preiss, W.V., 1987. The Adelaide Geosyncline. Department of Mines and Energy, Geological Survey of South Australia, Bulletin $N 53,438 \mathrm{p}$.

Purucker, M.E., Elston, D.P. and Shoemaker, E.M., 1980. Early kequisition of charecteristic magnetization in red beds of the Moenkopi Formation (Triassic), Gray Mountain, Arizona. Journal of Geophysical Research, v. 85, B2, p. 997-1102.

Ronov, A.B., Khain, V.E. and Seslavinskiy, K.B., 1981. Vendian lithological complexes of the world. Sovetskaya Geologia, no. 5, p. 37-59 (in Russian).

Roy, J.L., 1977. La position stratigraphique determinée paleomagnetiquement de sediments carboniferous de Minudie Point, Nouvelle Ecosse: a propose de l'horizon repere magnetique du carbonifere. Canadian Journal of Earth Sciences, v. 14, no. 5, p. $1116-1127$.

Roy, J.k. and Park, J.K., 1969. Paleomagnetism of the Hopewell Group, New Beunswick. Journal of Geophysical Research, v. 74, p. 594-604.

Roy, J.L. and Park, J.K., 1974. The magnetization process of certain red-beds: yector anelysis of chemical and thermal results. Canadian Journal of Earth Sciences, v. 11, no. 3, p. $437-471$.

Roy, J.L. and Robertson, W.A., 1968. Evidence for diagenetic remanent magnetization in the Maringouin Formation: Canadian Journal of Earth Sciences, v. 5, no. 2, p. $275-285$,

Roy, J.L. and Robertson, W.A., 1978. Paleomagnetism of the Jacobsville Formation and the apparent polar path for the interval -1100 to $-1670 \mathrm{~m} . \mathrm{y}$. for North America. Jounal of Geophysical Research, v, 83, B3, p. 1289-1304.

kuncorn, 0.k. (ed.), 1970. Paleogeophysics. Academic Press, London and New York, 5 I $8 \mathrm{p}$.

Schermerhorn, L.J.G. 1974. Late Precambrian mixtites: Glacial or non-glacial? American Journal of Science, v. 274, p. 673-824.

Schermerhorn, L.J.G., 1983. Late Proterozoic glaciation in the light of $\mathrm{CO}_{2}$ depletion in the atmosphere. In: Mendaris, L.G., Byers, C.W., Mickelson, D.M. and Shanks, W.C. (eds.), Proterozoic Geology. Geological Society of Anerica Memoir 181, p. 309-3!5.

Semikhatov, M.A., 1974. Stratigraphy and geochronology of Proterozoic. Nauka, Moscow, 299p. (in Russian).

sheldon, R.P., 1984. The Precambrian ice-ring model to account for changes in exogenic regimes from Proterozoic to Phanerozoic eras. In: Symposium of 5 th Interngtional field workshop and seminar on phosphorite, Kunming, China 1982 , v. 2, Peking, p. 227-243 (in Chinese, with English summary).

Sokolov, B.S., Ivanorskii, A.B. and Fedonkin, M.A. (eds.), 1985. The Vendian System: Historical, Geological and Paleontological Basis. Nauka, Moseow, v. 1, 22lp. and v. $11,237 \mathrm{p}$. (in Russian).

Spencer, A.M., 1971. Late Pre-Cambrian glaciation in Seotland. Geological Society of London, Memoir no. 6, 100p.

Steiner, M.B., 1988. Paleomagnetísm of the Late Pennsylvanian and Permian: $A$ test of the rotation of the Colorado Plateau. Journal of Geophysical Research, v. 93, no. B3, p. $2201-2215$.

Stocklin, J, 1968. Structural history and tectonies of tran: A review. American Association of Petroleum Geologists Bulletin, v. 52, no. 7, p. I229-1 258.

Tacling, D.H., 1974. A palaeomagnetic study of Eacambrian tillites in Scotland, Journal of the Geological Society of London, $v 130$, pt. 2, p. 163-177.

Trompette, R., 1973. Le Précambrien Supërieur et le paléozoique inférieur de lAdrar de Mauritanie; I, II, III. Travaux des Laboratoires des Sciences de la Terre, St. Jérôme, Marsellle ( 8 ), no. 7, 702p.

Vinogradov, A.P., 1967. Atlas of the Lithological-Paleogeographical Maps of the U.S.S.R, Moscow, U.S.S.R. Ministry of Geology, $x, L, 50 p$. (in Russian).

Volin, A.V., 1966. Slide breccias and tillites: Their relations with problems of glaciations and pole drift. Abstracts of meeting "General regularities of geological events," Leningrad, Part 1, p. 36-40 (in Russian).

Williams, G.E., 1975. Late Precambrian glacial climate and the Earth's obliquity. Geological Magazine, v. 112 , no. 5, p. 441-465.

Young, G.M. 1970. An extensive early Proterozoic glaciation in North America. Palaeogeography, Palaeoclimatology and Palaeoeeology, v. 7 , no. z, p. 85-101.

Young, G.M., 1981. Upper Proterozoic supracrustal rocks of North America: A brjef review. Precambrian Research, v. 15, no. 3-4, p. 305-330.

Zhang Huimin, Elston, D.P. and Zhang Wenzhi, 1989. Paleomagnetism of Viddle and Late Proterozoic Dagushi, Huashan, and Sinian Groups, Jingshan County, Hube Province, South China. Abstracts with Program, 28th International Geological Congress, Washington, D.C.

Zhuhong, 1983. A study on the paleomagnetism of the manganiferous rock series in Sinian Datangro members. International Symposium on Late Precambrian Geology, China, Tianjin, ?. 72.

Zubtsov, E.L., 1972. Precambrian tillites of Tien Shan and their stratigraphic significance. Bulletin, Moscow Society of Naturalists, Geological Part, no. 1, p. 42-56 (in Russian). 